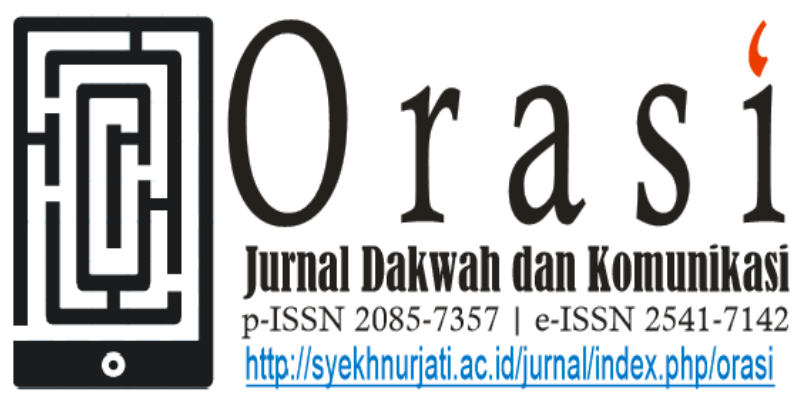

Volume 9 No. 1 PP 1 - 14 Juli 2018

\title{
PERSONAL BRANDING PEJABAT PUBLIK DI MEDIA SOSIAL
}

\author{
Hanifah Islamiyah1(*), Arief Rachman ${ }^{2}$ \\ Mahasiswa Jurusan Komunikasi dan Penyiaran Islam ${ }^{1}$ \\ Dosen Jurusan Komunikasi dan Penyiaran Islam ${ }^{2}$ \\ Fakultas Ushuluddin Adab dan Dakwah IAIN Syekh Nurjati Cirebon \\ $\underline{\text { miahanifah.abz@gmail.com }}^{(*)}$ arief.rachman@syekhnurjati.ac.id
}

\begin{abstract}
ABSTRAK
Pengguna media sosial semakin banyak, berbanding lurus dengan minat anak muda terhadap isu-isu politik. Media sosial dan politik menjadi satu mata rantai yang penting dalam terjalinnya komunikasi politik. Dengan dilatarbelakangi hal tersebut peneliti tertarik untuk menggali informasi mengenai personal branding pejabat publik Nasrudin Azis, Walikota Cirebon 2013-2018, melalui akun media sosial Facebook dan Instagram dan personal branding yang paling dominan dibangun di media sosial.Penelitian ini bertujuan untuk mencari citra yang ingin ditunjukkan Nasrudin Azis dalam akun Facebook dan Instagramnya, dan citra yang paling menonjol ditunjukkan Nasrudin Azis dalam akun Facebook dan Instagramnya. Berdasarkan hasil penelitian mengenai personal branding yang ditunjukkan Nasrudin Azis di akun Facebook dan Instagram dan personal yang paling dominan menunjukkan bahwa; (1) Personal branding yang dibentuk Nasrudin Azis di akun Facebooknya adalah Spesialisasi; behaviour, mission, lifestyle, product, service, kepemimpinan, kepribadian, perbedaan, visiability dan keteguhan. (2) Personal branding yang dibentuk Nasrudin Azis di akun Instagram adalah spesialisasi; ability, lifestyle, product dan service, kepribadian, perbedaan, visiability, kesatuan, keteguhan dan goodwill. Dan hasil perhitungan persamaan paling tinggi dari tiga tabel penilaian pengkoding, hasilnya dapat disimpulkan bahwa personal branding yang paling dominan di akun Facebook Nasrudin Azis adalah Spesialisasi dan personal branding yang paling dominan di akun Instagram Nasrudin Azis adalah perbedaan.
\end{abstract}

Kata kunci: Personal branding, pejabat publik, media sosial, facebook, instagram 


\section{Pendahuluan}

Komunikasi politik menggunakan teknologi komunikasi sampai saat ini masih efisien untuk digunakan. Puncaknya sampai penggunaan internet atau international networking memudahkan proses komunikasi dan informasi manusia. Informasi dari seluruh penjuru dunia bisa diakses dengan mudah hanya dengan cara terhubung dengan internet. Pekerja dan pelajar lebih dimudahkan pekerjaannya dengan cara perangkat informasi terhubung internet.

Setelah teknologi internet kian maju, internet bisa digunakan oleh seluruh kalangan masyarakat. Tidak hanya bagi kalangan eksekutif, tapi juga bisa digunakan oleh seluruh latar belakang ekonomi, pendidikan dan pekerjaan. Hal tersebut terjadi berkat akses internet semakin murah dan era teknologi digital telah memudahkan seluruh masyarakat menggunakan telefon pintar (Anwar, 2011).

Menurut Hasil survey Asosiasi Penyelenggara Jasa Internet Indonesia (APJII) tahun 2017 menyatakan bahwa dari 256,2 Juta penduduk Indonesia, 143,26 Juta ialah pengguna internet (APJII, 2017). Hasil lain dari survei APJII terhadap pengguna internet Indonesia ialah $89 \%$ pengguna internet memilih jenis konten internet yang diakses adalah media sosial. Survey media sosial yang sering dikunjungi pada survei APJII tahun 2016, ialah Facebook dengan 71,6 Juta pengguna (APJII, 2016). Adapun jenis konten internet ketiga tersering diakses selain media sosial yakni berita, memuat prosentase konten berita yang paling sering dikunjungi pada tahun 2017, $36,94 \%$ pengguna internet mengunjungi berita politik, meningkat dari tahun 2016 yang hanya $11 \%$.

Berdasarkan tiga hasil survey APJII di atas, peneliti tertarik untuk mendalami fakta mengenai media sosial yang digunakan sebagai media mengkomunikasikan politik. Sesuai dengan perkembangan zaman, pejabat publik dituntut untuk mampu mengikuti cara dan model komunikasi politik yang bisa diterima masyarakat modern. Indonesia sebagai pengguna internet tinggi di dunia juga menekan pejabat publik untuk turut aktif dan siap melakukan transparansi kegiatannya melalui media massa.

Adapun tokoh pejabat publik Indonesia yang menggunakan media massa cukup banyak. Presiden Republik Indonesia Joko Widodo, Gubernur DKI Jakarta Anies Baswedan, dan Walikota Bandung Ridwan Kamil. Media massa yang dipilih pun beragam, Presiden RI baru-baru ini sering menggunakan media 
sosial Youtube mengenai "blusukannya", Anies Baswedan melalui televisi, dan Ridwan Kamil melalui media sosial Instagram dengan cara yang humor namun mendidik.

Konten ataupun kiriman yang diunggah di media massa secara kontinu dan terkonsep, akan membangun pandangan masyarakat. Presiden RI Joko Widodo yang terus menerus mengunggah video "blusukannya" di Youtube, telah membangun persepsi dan pandangan terhadap Joko Widodo bahwa ia adalah seseorang yang sederhana, pekerja keras, dan rendah hati. Postingan humor yang diunggah di Instagram oleh akun Ridwan Kamil membangun persepsi masyarakat mengenai sosok Walikota Bandung yang humoris, santai dan segar.

Pandangan dan persepsi publik secara langsung telah membentuk citra dari sosok pejabat publik. Citra baik ataupun buruk dapat dibangun melalui media sosial, karena media sosial akan mendekatkan tokoh pejabat publik secara fiktif namun mendalam, bisa dilakukan secara terus menerus, dan mudah menjangkau seluruh lapisan masyarakat.

Selain karena penggunaan komunikasi politik melalui media sosial semakin marak, tahun 2017 sampai tahun 2018 merupakan tahun politik yang akan terselenggaranya Pemilihan Kepala Daerah Serentak tahun 2018 dan Pemilihan
Presiden pada tahun 2019. Walaupun tidak berlangsung pada tahun 2017, namun merupakan tahun terakhir penghabisan masa jabatan kepala daerah terpimpin. Sekaligus merupakan tahun yang rawan kampanye terselubung bagi bakal calon kepala daerah yang akan mencalonkan.

Komisi Pemilihan Umum Republik Indonesia (KPU RI) mengumumkan ada 171 daerah yang akan mengikuti Pemilihan Kepala Daerah (Pilkada) Serentak pada 27 Juni 2018. Terdiri dari 17 Provinsi, 39 Kota dam 151 Kabupaten. Salah satu dari kota yang mengikuti Pilkada Serentak ialah Kota Cirebon (Nn, 2017).

Kota Cirebon terakhir melakukan Pilkada pada tahun 2013 dengan pasangan walikota terpilih yakni Ano Sutrisno Nasrudin Azis. Namun, ditengah masa jabatannya, Ano Sutrisno meninggal dunia pada tahun 2015. Nasrudin Azis selaku Wakil Walikota melanjutkan sisa masa jabatan sampai tahun 2018. Nasrudin memimpin Kotamadya seorang diri tanpa wakil sampai di ujung masa jabatannya ${ }^{1}$.

Pencalonan wakil walikota bagi Nasrudin sempat berlangsung ramai diperbincangkan warga Kota Cirebon di media cetak dan portal online lokal sampai

11 http://www.rakyatcirebon.co.id/2016/06/tidakada-wawali-sampai-2018.html diakses pada hari Senin, 22 Januari 2018 pukul 1:22 
nasional2. Partai pengusung Ano-Azis tidak memberikan nama calon wakil walikota ke Panitia Pemilihan (Panlih) sampai batas waktu yang ditentukan. Pemilihan wakil walikota bagi Azis pun tertutup kemungkinan dengan semakin dekat berakhirnya masa jabatan.

Meskipun dalam beberapa pemberitaan Azis mengaku kewalahan dalam memimpin pemerintahan Kota Cirebon, hal tersebut tidak mengurungkan Aziz untuk maju kembali dalam Pilwalkot 2018. Nasrudin Azis telah mendaftar di KPU untuk pencalonannya bersama Eti Herwati sebagai calon wakil walikota3. Berkas pengajuan cuti pun sudah Azis serahkan pada tanggal 19 Januari 2018 pada KPU. Azis pun menyatakan, melalui media, bahwa Azis berharap pejabatpejabat lain dapat melakukan pekerjaannya dengan baik 4 .

Pencalonannya sebagai petahana di ajang Pilwalkot 2018 tidak mudah. Pada pertengahan 2017 telah muncul 10 nama bakal calon walikota Kota Cirebon yang dikeluarkan media lokal. Toto Sunanto, Lili Eliyah, Brigjen Pol Siswandi, Bamunas Setiawan Boediman (Oki), drg Heru Purwanto, dr Assad, Efendi Edo, Fifi

2http://regional.kompas.com/read/2017/01/19/15010031/dua.tah un.tanpa.pendamping.wali.kota.cirebon.kewalahan diakses pada hari Senin, 22 Januari 2018 pukul 1:23

3 https://aboutcirebon.id/hari-terakhir-pendaftaran-pasanganazis-eti-resmi-daftar-ke-kpu-kota-cirebon/diakses pada hari Senin, 22 Januari 2018 pukul 1:24

4 http://jabar.tribunnews.com/2018/01/19/nasrudin-azis-akanserahkan-surat-cuti-ke-kpu-kota-cirebon-hari-inidiakses pada hari Senin, 22 Januari 2018 pukul 1:26
Sofiah, M Reza, dan Andri Sulisto.Namun, sampai diakhir penutupan masa pendaftaran walikota-wakil walikota Kota Cirebon, telah terdaftar hanya dua pasang. Bamunas Setiawan Boediman berpasangan dengan Effendi Edo head to head dengan petahana dan pasangan.

Menurut KPU DIY5, dalam website resminya, hal yang harus diperhatikan pertama kali dalam menentukan pilihan memilih pemimpin, pertama adalah dari rekam jejaknya. Namun apabila calon yang ada belum pernah memimpin, maka rekam jejak dapat dilihat dari riwayat hidup dan visi-misinya. Kota Cirebon memiliki dua pasang calon, yang satu petahana dan lainnya ialah basic pengusahawan. Nasrudin Azis memiliki rekam jejak yang menarik yang patut diikuti untuk bisa menjadi bahan pertimbangan sekaligus sebagai rapot personal branding yang selama masa kepemimpinannya dibentuk.

Hal yang menarik dari cara kepemimpinan Nasrudin Azis, ialah penggunaan media sosial sebagai media komunikasi politik. Nasrudin menggunakan media sosial Facebook dan Instagram, yang seperti hasil survey APJII Tahun 2016 di atas, merupakan media sosial yang paling banyak digunakan

5 http://diy.kpu.go.id/web/2016/06/27/memilihpemimpin-berkualitas/ diakses pada hari Senin, 22 Januari 2018 pukul 1:27 
pengguna internet Indonesia. Nasrudin Azis menggunakan kedua akun tersebut sebagai tokoh pejabat publik, bukan sebagai keperluan pribadi. Ia membagikan kesehariannya sebagai Walikota Cirebon ${ }^{6}$.

Isu citra politik pejabat publik penting untuk dikaji mengingat pentingnya nilai yang harus dipertimbangkan masyarakat dalam memilih pemimpin daerah. Citra politik Nasrudin Azis, sebagai Walikota pertama di Cirebon yang menggunakan media sosial secara aktif sebagai alat komunikasi politik, bisa dijadikan prototipe bagi pejabat publik di Cirebon atau justru pelajaran.

Aktor politik memilik tujuan untuk meningkatkan tingkat elektabilitas masyarakat terhadap dirinya, dan peningkatan nilai mutu dalam pembentukan citra politik.

Berdasarkan masalah tersebut, peneliti merasa tertarik untuk meneliti komunikasi politik yang digunakan Nasrudin Azis untuk membangun citra personalnya melalui media sosial yang dimiliki.

\section{METODOLOGI PENELITIAN}

\section{a. Jenis Penelitian}

Jenis penelitian yang digunakan yaitu penelitian kuantitatif. Kuantitatif adalah sebuah nilai yang dikandung oleh

6http://jabar.tribunnews.com/2018/01/10/didukungbanyak-partai-petahana-kota-cirebon-optimistismenang-pilkada-2018 diakses pada hari Senin, 22 Januari 2018 pukul 1:28 sesuatu atau sebuah benda yang penelitiannya dilakukan akan didasarkan pada mutu dan kualitas yang terkandung di dalamnya, menurut Kriyantono. (Kriyantono, $2006: 67$ )

Peneliti kuantitatif harus objektif dan memisahkan diri dari data. Data harus dinilai, diprauji dan diuji alat ukurnya sudah memenuhi prinsip data reliabilitas dan validitas oleh pengkoding. Hal ini disebabkan, kuantitaitf memiliki beberapa ciri. Cirinya yaitu bertujuan untuk menguji teori atau hipotesis yang sudah ada. (Rahmat, 2014 : 176)

Kuantitatif menurut Kriyantono (2006: 58), peneliti harus membuat definisi konseptual tentang teori. Setelah itu, dibuat definisi operasional, yang mendefinisikan secara deskriptif definisi konseptual. Ia mencontohkan definisi konseptual cantik, maka definisi operasionalnya adalah hitam manis, ideal, rambut indah, jari lentik dan sebagainya. Setelah itu, hasil dari definisi operasional dibuat pertanyaan dalam tabel, dari hasil pengamatan pengkoding, definisi operasional A mencakup daripada definisi konseptual atau tidak. Pertanyaan ini disebut ukuran objektivitas di luar periset, yakni hakim/pengkoding yang memiliki keahlian, keilmuan dan kompeten dalam bidangnya. (Kriyantono, 2006 : 58) 


\section{b. Pendekatan Penelitian}

Descriptive content analysis atau analisis isi deskriptif menurut Bernard Barelson adalah teknik riset untuk objektifitas, sistematis, dan deskriptif kuantitatif dari apa yang tampak dalam komunikasi. Jenis riset deskriptif bertujuan membuat deskripsi yang sistematis, akurat dan faktual mengenai objek penelitian. Peneliti membuat konsep dan kerangka konseptual, kemudian melakukan operasionalisasi konsep yang akan menghasilkan variabel dan indikatornya. Riset deskriptif bertujuan utama menggambarkan realitas yang terjadi, tanpa hubungan antarvariabel atau sebab-akibat variabel. (Suharsaputra, 2012 : 105)

\section{c. Teknik Pengumpulan Data \\ 1. Dokumentasi}

Dokumenter adalah salah satu pengumpulan data yang digunakan dalam metodelogi penelitian sosial. Pada intinya, metode dokumenter ialah metode yang digunakan untuk menelusuri data historis. (Bungin, 2007 : 124)

Dokumentasi dalam penelitian ini berupa hasil screencapture postingan di akun media sosial Facebook dan Instagram Nasrudin Azis selama tahun
2017. selain itu, dokumen seperti buku yang terkait penelitian, jurnal, juga termasuk sumber data dokumentasi. dokumentasi juga berupa foto saat pengkoding sedang memberi nilai.

2. Observasi

Observasi merupakan metode pengumpulan data yang mengamati interaksi (perilaku) dan percakapan yang terjadi di antara subjek yang diriset. Observasi dalam penelitian ini menggunakan mediator untuk mengobservasi objek penelitian. Jenis observasi yang digunakan adalah covertobservation, ialah peranan periset terbatas sebagai observer karena membutuhkan hakim/coder lain yang lebih kompeten, dan subyek yang diriset tidak menyadari keberadaan periset sehingga tidak tahu jika sedang diriset. (Kriyantono, 2010 : 111).

Observasi dilakukan saat peneliti membuat unit analisis, definisi konsep dan definisi operasi dan membuat deskripsi. hampir secara keseluruhan penelitian ini peneliti melakukan observasi kepada objek penelitian. namun, untuk memperkuat validitas observasi peneliti, dibutuhkan penilaian dari ahli agar hasil dari penelitian objektif.

3. Intrumen pengumpulan data

Instrumen pengumpulan data adalah seperangkat alat yang dibuat oleh 
periset lengkap dengan pedoman coder untuk mengisi tabel unit analisis dan teknik analisis data. Intrumen itu akan berisi aturan yang harus dilakukan oleh periset, apa saja yang harus dilakukan periset, format nilai yang akan digunakan periset dan tabel yang akan diisi oleh periset.

Instrumen pengumpulan data adalah berupa draft yang berisi kriteria pengkoding, pedoman mengisi tabel, screen capture unggahan Facebook dan Instagram beserta deskripsinya masingmasing, dan tabel penilaian. Instrumen ini sangat penting karena menjadi alat untuk mengukur personal branding yang akan diteliti. Intrumen pengumpulan data ini akan menghasilkan apa saja personal branding yang dibangun nasrudin azis di media sosialnya, dan personal branding yang paling menonjol.

\section{d. Penetuan dan Kriteria Pengkoding}

Sehubungan dengan wilayah kajian skripsi ini adalah komunikasi politik, maka untuk menilai personal branding yang ditampilkan di media sosial milik pejabat publik, dibutuhkan penilaian seorang ahli dari bidang komunikasi dan politik. Selain itu, berikut adalah kriteria pengkoding ;

1. Berprofesi sesuai pada bidangnya. bekerja di media atau akademisi komunikasi dan bekerja di instansi lembaga hukum atau akademisi hukum.

2. Bertempat tinggal dan atau lahir di Cirebon.

3. Mampu memahami penilaian intrumen pengumpulan data.

\section{e. Populasi dan Teknik Sampling}

Populasi adalah keseluruhan objek atau fenomena yang diriset. Dalam melakukan penelitian, peneliti harus mengumpulkan dan menjumlah keseluruhan objek. Setelah dikumpulkan, kemudian diamati. Setelah melakukan pengamatan, peneliti baru bisa menentukan teknik sampling yang akan digunakan untuk menemukan sebagian jumlah yang akan dilakukan pengamatan. Jumlah populasi objek penelitian ada 560 unggahan,

Teknik sampling yang akan digunakan oleh peneliti ialah sampling random sederhana. Teknik ini menganggap bahwa setiap anggota populasi memeiliki peluang yang sama untuk menjadi sampel. Periset menulis atau memberi nomor pada setiap populasi dalam selembar kertas, kemudian mengundinya dengan acak smapai mendapatkan sejumlah sampel yang dibutuhkan. Syarat teknik ini ialah membuat kerangka sampel terlebih dahulu. Melalui teknik ini, mengetahui detail setiap populasi tidak penting. Reperesentasi tiap kelompok mudah 
ditemukan dan kemungkinan kesalahan pengklasifikasian sangat kecil. (Kriyantono, $2006: 153$ )

Teknik analisis data yang akan digunakan ialah tabel berisi Teori Delapan Konsep Personal Branding Peter Montoya. Coder akan menganalisis sampel yang sudah ditentukan, kemudian coder akan memberi nilai sesuai intrumen yang sudah adai di pedoman. Setelah itu, hasil dari dua coder dalam penilaian, akan dihitung menggunakan Teori Holsti

Sampel ialah sebagian objek yang akan dilakukan pengamatan. Hal ini dilkukan karena keterbatasa yang dimiliki periset, baik biaya, waktu dan tenaga. Praktiknya, periset mampu meneliti keseluruhan obyek hanya dengan melakukan pengamatan dengan beberapa bagian dari keseluruhan obyek. Beberapa bagian yang dipilih dari keseluruhan obyek disebut sampel. (Kriyantono, $2006: 243$ )

\section{f. Uji Validitas Instrumen}

Uji Validitas berasal dari kata validity yang mempunyai arti sejauh mana ketepatan dan kecermatan suatu alat ukur dalam melakukam fungsi ukurannya. Selain itu validitas adalah suatu ukuran yang menunjukkan bahwa variabel yang diukur memang benarbenar variabel yang hendak diteliti oleh peneliti (Kriyantono, 2006 : 238).
Validitas berhubungan dengan suatu peubah mengukur apa yang seharusnya diukur. Validitas dalam penelitian menyatakan derajat ketepatan alat ukur penelitian terhadap isi sebenarnya yang diukur. Uji validitas adalah uji yang digunakan untuk menunjukkan sejauh mana alat ukur yang digunakan dalam suatu mengukur apa yang diukur. Uji validitas digunakan untuk mengukur sah, atau valid tidaknya suatu kuesioner. Suatu kuesioner dikatakan valid jika pertanyaan pada kuesioner mampu untuk mengungkapkan sesuatu yang akan diukur oleh kuesioner tersebut.

Suatu tes dapat dikatakan memiliki validitas yang tinggi jika tes tersebut menjalankan fungsi ukurnya, atau memberikan hasil ukur yang tepat dan akurat sesuai dengan maksud dikenakannya tes tersebut. Suatu tes menghasilkan data yang tidak relevan dengan tujuan diadakannya pengukuran dikatakan sebagai tes yang memiliki validitas rendah.

Sisi lain dari pengertian validitas adalah aspek kecermatan pengukuran. Suatu alat ukur yang valid dapat menjalankan fungsi ukurnya dengan tepat, juga memiliki kecermatan tinggi. Arti kecermatan disini adalah dapat mendeteksi perbedaan-perbedaan kecil 
yang ada pada atribut yang diukurnya (Kriyantono, 2006 : 239).

Jenis uji validitas yang digunakan adalah contruct validity, yaitu derajat kesesuaian teori dan konsep yang dipakai dengan alat pengukuran yang dipakai dalam penelitian bersangkutan. Alat pengukuran yang digunakan dalam penelitian ini ialah draft panduan pengisian tabel penilaian dan tabel penilaian yang akan diisi oleh coder (Kriyantono, $2010: 250$ ).

Kategorisasi dalam analisis isi merupakan instrumen pengumpul data. Fungsinya untuk membuat kuesioner dalam survei. Supaya objektif, maka kategorisasi harus dijaga reliabilitasnya. Terutama untuk kategorisasi yang dibuat oleh penelitinya sendiri seperti penelitian yang akan dibuat. Uji reliabilitas yang akan digunakan dalam penelitian ini adalah rumus Holsty dan jenisnya adalah intercoder-intracoder, yakni penilaian dari dalam (peneliti) dan dari luar (coder/hakim yang kompeten dalam bidangnya) (Kriyantono, $2010: 238$ ).

Rumus Holsty yang akan digunakan yakni ;

$$
C R=\frac{2 M}{N 1+N 2}
$$

Keterangan :

CR : Coeficient reliability

M : Jumlah pernyataan yang disetujui oleh pengkoding (hakim) dan periset
NI, N2 : Jumlah penyataan yang diberik oleh pengkoding (hakim) dan periset

Apabila hasil perhitungan di atas menunjukkan lebih dari 0,7 atau $70 \%$, maka artinya hasil riset pengkoding valid. Hasil pengkoding yang valid akan menemukan hasil bahwa personal branding apa yang paling dominan ditampilkan dalam akun Facebook dan Instagram Nasrudin Azis.

\section{g. Profil Nasrudin Azis7}

Drs. Nasrudin Azis, S.H. di lahirkan di Cirebon pada 20 Oktober 1965, saat ini menjabat sebagai Wali kota Cirebon untuk periode 2013-2018 menghabiskan sisa jabatan sepeninggal wafatnya Wali Kota Cirebon Alm. Drs. H Ano Sutrisno, M.M.

Keluarga

Ayah : H. Mohamad Tamsur (Alm)

Ibu : Hj. Munijah

Istri : Ginawati Limansyah

Anak Pertama : Victor Pikiran Kotor

Anak Kedua : Octaviano Leonarto

Anak Ketiga : Aulia Septian Nugraha

Pendidikan

SD : SDN Kebon Baru III Kota Cirebon, lulus pada tahun 1979

SMP : SMPN 1 Kota Cirebon, lulus pada tahun 1982

7 Lembar profil mengutip sepenuhnya dari https://id.wikipedia.org/wiki/Nasrudin_Azis pada tanggal 19 Januari 2018 pukul 22;15 
SMA : SMAN 1 Kota Cirebon, lulus pada tahun 1985

S1 Management FPOK IKIP Bandung (sekarang UPI) lulus pada tahun 1989

S1/Hukum Universitas 17 Agustus

$\underline{1945}$ Kota Cirebon, lulus pada tahun 1990

S2 Universitas Pasundan (Masih Berjalan)

Pekerjaan

1995 - sekarang : GM Hotel Baru, Cirebon

2009 - 2013 : Ketua DPRD Kota Cirebon

2013 - 2015 : Wakil Wali Kota Cirebon

2015 - Sekarang : Wali Kota Cirebon

2003 - sekarang : Anggota Partai

Demokrat

2005 - sekarang : Anggota Pemuda

Pancasila Kota Cirebon

2006 - sekarang : Ketua DPC Partai

Demokrat Kota Cirebon

2015 - sekarang : Ketua MPO Pemuda

Pancasila

2015 - sekarang : Ketua Kwartir Cabang

Gerakan Pramuka Kota Cirebon

\section{HASIL DAN PEMBAHASAN}

\section{Personal Branding yang Ditampilkan Nasrudin Azis di} Akun Facebook dan Instagramnya

Ada sebelas unggahan Nasrudin Azis yang bernilai personal branding spesialisasi, namun hanya empat dimensi yang terkandung dalam unggahan Nasrudin Azis, behaviour, lifestyle, product, dan service. Tidak ada unggahan yang mengandung spesialisasi dimensi ability, mission dan professions.

Unggahan lainnya yakni satu unggahan mengandung nilai kepemimpinan, empat unggahan mengandung nilai kepribadian, satu unggahan bernilai visiability, dua unggahan personal branding perbedaan, kesatuan dan keteguhan. Semua unggahan yang menjadi sampel mengandung nilai personal branding dilihat dari jumlah total.

Hasil penilaian pengkoding 1, tidak ada unggahan di akun Facebook dan Instagram Nasrudin Azis yang tidak mengandung nilai personal branding. Bahkan seluruh kategorisasi personal branding menurut Peter Montoya dapat ditemukan di unggahan Nasrudin Azis.

Tabel penilaian pengkoding 2 diisi oleh pengkoding ahli. Penilaian dapat disimpulkan beberapa hal, yakni diantaranya dari teori delapan konsep personal branding Peter Montoya, seluruhnya terkandung dalam seluruh sampel yang diuji. Duabelas diantaranya mengandung nilai visiability, sembilan unggahan mengandung nilai perbedaan, satu unggahan mengandung kesatuan. Personal branding yang dibentuk Nasrudin Azis di akun Facebooknya ada tiga nilai, yakni perbedaan dan visiability. Personal branding spesialisasi, kepemimpinan, kepribadian, kesatuan, 
keteguhandan goodwill tidak dibentuk oleh Nasrudin Azis di akun Facebooknya melalui unggahan yang dikirim. Sedangkan personal branding yang dibangun oleh Nasrudin Azis melalui unggahannya di Instagram ada perbedaan, visiabilitydankesatuan.Semua unggahan yang menjadi sampel mengandung nilai personal branding dilihat dari jumlah total yang dinilai oleh Pengkoding 2.

\section{Personal Branding Paling Dominan} di Akun Facebook dan Instagram Nasrudin Azis

\section{a. Personal Branding Paling Dominan di Akun Facebook}

Personal branding yang dibentuk Nasrudin Azis di akun Facebooknya menurut Peneliti ada lima nilai, yakni Spesialisasi; behaviour, lifestyle, product, service, Kepemimpinan, Kepribadian, Perbedaan, dan Visiability. Personal branding kesatuan, keteguhan dan goodwill tidak dibentuk oleh Nasrudin Azis di akun Facebooknya melalui unggahan yang dikirim. Total, enam unggahan bernila ispesialisasi, satu unggahan bernila ikepemimpinan, kepribadian, perbedaan, danvisiability. Jumlah total 10 unggahan.

Keseluruhan sampel dari media sosial Facebook, terkandung enam nilai personal branding. Spesialisasi ; behaviour, mission, kepemimpinan, kepribadian, perbedaan, kesatuan dan keteguhan. Tidak ada dimensi ability, lifestyle, product, dan profession dalam nilai spesialisasi di dalam unggahan Nasrudin Azis di Facebook. Tidak ada juga nilai visiability dan goodwill dalam sepuluh sampel unggahan Facebook Nasrudin Azis.

Penilaian Pengkoding 1, personal branding yang dibentuk Nasrudin Azis di akun Facebooknya ada dua nilai, yakni perbedaan dan visiability. Personal branding spesialisasi, kepemimpinan, kepribadian, kesatuan, keteguhandan, goodwill tidak dibentuk oleh Nasrudin Azis di akun Facebooknya melalui unggahan yang dikirim.Tiga unggahan bernilai perbedaan dan tujuh unggahan bernilai visiability.

Dari tabel penilaian, dapat disimpulkan nilai personal branding spesialisasi berjumlah 9 unggahan, kepemimpinan berjumlah 4 unggahan, kepribadian berjumlah 2 unggahan, perbedaan berjumlah 5 unggahan, visiability berjumlah 8 unggahan, kesatuan berjumlah 1 unggahan, keteguhan berjumlah 1 unggahan, dan goodwill tidakada. Jumlah totalnya ada 10 unggahan yang dinilai pengkoding.

Nilai-nilai personal branding yang terkandung di unggahan Facebook Nasrudin Azis menurut penilaian 
Pengkoding 2 adalah spesialisasi dengan dimensi behaviour, lifestyle, mission, product dan service, kepemimpinan, kepribadian, perbedaan, visiability, kesatuan dan keteguhan. Penilaian pengkoding tidak ada nilai goodwill dalam unggahan di Facebook.

Personal branding yang paling dominan dapat ditemukan dengan menghitung jumlah penilaian yang sama. Persamaan yang paling tinggiadalah 9 unggahan. maka, apabiladihitung menggunakan rumus Holstyadalah ;

$$
\mathrm{CR}=\frac{2.9}{10+10}=\frac{18}{20}=0,9
$$

Keterangan :

$\mathrm{CR}$ : Coeficient reliability

M : Jumlah pernyataan yang disetujui oleh pengkoding (hakim) dan periset NI, N2 : Jumlah penyataan yang diberik oleh pengkoding (hakim) dan periset

Hasil 0,9 atau 90\% membuktikan bahwa tabel penialaian di atas valid karena di atas 0,7 atau 70\%. Maka, dapat disimpulkan bahwa personal branding yang paling dominan di akun Facebook Nasrudin Azis adalah Spesialisasi.

\section{b. Personal Branding Paling Dominan} di Akun Instagram Nasrudin Azis

Personal branding yang dibangun oleh Nasrudin Azis menurut Peneliti melalui unggahannya di Instagram ada empat nilai. Spesialisasi ; lifestyle, product, Kepribadian,perbedaan,
Kesatuan, dan Keteguhan. Dari personal branding spesialisasi yang terkandung dalam postingan Instagram Nasrudin Azis hanyadimensi lifestyle dua unggahan dan product tiga unggahan, total lima postingan yang terkandung nilai spesialisasi. Nilai kepribadian terkandung di dua unggahan, perbedaan pada satu unggahan, dua unggahan bernilai kesatuan dan keteguhan.

Nilai personal branding yang terkandung dalam unggahan di akun Instagram Nasrudin Azis menurut Pengkoding 1, hampir semuanya ada kecuali kepemimpinan, tidak ada unggahan di akun Instagram Nasrudin Azis yang mengandung nilai kepemimpinan. Selain itu, tidak ada dimensi behaviour, lifestyle, mission, product dan profession dalam nilai spesialisasi yang terkandung di seluruh sampel unggahan Instagram. Hanya ada dimensi ability dan service.

Rinciannya, personal branding spesialisasiadaduadimensi yang terkandung di unggahan Nasrudin Azis yakni ability dan service. Kepribadian terdapat di tiga unggahan, perbedaan dapat ditemukan di duaunggahan, visiability, kesatuan dan keteguhan terkandung di masing-masing satu unggahan, dan dua unggahan yang bernilai goodwill. 
Menurut Pengkoding 2, personal branding yang dibangun oleh Nasrudin Azis melalui unggahannya di Instagram ada perbedaan, visiability dan kesatuan. Enam unggahan mengandung nilai perbedaan, lima unggahan mengandung nilai visiability dan satu unggaha nmengandung kesatuan.

Dari table penilaian, dapat disimpulkan nilai personal branding spesialisasi berjumlah 6 unggahan, kepemimpinan tidak ada, kepribadian berjumlah 5 unggahan, perbedaan berjumlah 9 unggahan, visiability berjumlah 6 unggahan, kesatuan berjumlah 3 unggahan, keteguhan berjumlah 2 unggahan, dan goodwill berjumlah 2 unggahan. Jumlah totalnya ada 12 unggahan yang dinilai keseluruhan pengkoding.

Persamaan yang paling tinggiadalah 9 unggahan. maka, apabila dihitung menggunakan rumus Holstyadalah ;

$$
\mathrm{CR}=\frac{2.9}{12+12}=\frac{18}{24}=0,75
$$

Keterangan :

CR : Coeficient reliability

M : Jumlah pernyataan yang disetujui oleh pengkoding (hakim) dan periset NI, N2 : Jumlah penyataan yang diberik oleh pengkoding (hakim) dan periset
Hasil $\quad 0,75$ atau $\quad 75 \%$ membuktikan bahwa tabel penialaian di atas valid karena di atas 0,7 atau $70 \%$. Maka, dapatdisimpulkan bahwa personal branding yang paling dominan di akunInstagram Nasrudin Azis adalah perbedaan.

\section{KESIMPULAN}

Berdasarkan hasil penelitian mengenai personal branding yang ditunjukkan Nasrudin Azis di akun Facebook dan Instagram dan personal yang palingdominan seperti yang telah diuraikan, maka dapat ditarik kesimpulan sebagai berikut:

Personal branding yang dibentuk Nasrudin Azis di akun Facebooknya adalah Spesialisasi; behaviour, mission, lifestyle, product, service, Kepemimpinan, Kepribadian

\section{DAFTAR PUSTAKA}

Ardianto, Elvinaro, dkk. 2014. Komunikasi Massa. Bandung: Simbiosa Rekatama Media.

Arifin, Anwar. 2011. Sistem Komunikasi Indonesia. Bandung: Simbiosa Rekatama Media

Bungin, Burhan. 2007. Sosiologi Komunikasi. Jakarta : Kencana Prenada Media Group

DeVito, Joseph A. 2011. Komunikasi Antarmanusia. Jakarta: Karisma Publishing

Effendi, Onong Uchjana. 2004. Dinamika Komunikasi. Bandung: PT Remaja Rosdakarya 
2013. Ilmu Komunikasi Teori dan Praktek. Bandung : PT Remaja Rosdakarya

Kasali, Rhenald. 2013. Camera Branding Cameragenic VS. Auragenic. Jakarta: PT Gramedia Pustaka

Kriyantono, Rachmat. 2006. Riset Komunikasi. Jakarta: Kencana

Leakey, Richard. 2007. Asal-Usul Manusia. Jakarta: Kepustakaan Populer Gramedia

McQuail, Denis. 1994. Teori Komunikasi Massa. Jakarta: Erlangga.

Morissan, dkk. 2013. Teori Komunikasi Massa. Bogor: Ghalia Indonesia.

Nimmo, Dan. 2010. Komunikasi Politik Khalayak dan Efek. Bandung: Rosda Karya

Nurudin. 2013. Teori Komunikasi Massa. Jakarta: Erlangga.

Rachmat, Jalaludin. 2014. Metode Penelitian Komunikasi. Bandung : Rosda Karya

Rahmat, Jalaludin. 2007. Psikologi Komunikasi. Bandung: Remaja Rosdakarya

Rivers, William L dan Jay W. Jensen Theodore Peterson. 2004. Media Massa dan Masyarakat Moderen. Jakarta: Prenada Media.

Subiakto, Henry dan Ida, Rachmah. 2015. Komunikasi Politik, Media dan Demokrasi. Jakarta: Kencana

Suharsaputra, Uhar. 2012. Metode Penelitian Kuantitatif, Kualitatif, dan Tindakan. Bandung: PT Refika Aditama.

Tabroni, Roni. 2012. Komunikasi Politik pada era Multimedia. Bandung: Simbiosa Rekatama Media.

Wesfix, Tim. 2017. Branding itu “dipraktekin”. Jakarta: PT Grasindo http://www.rakyatcirebon.co.id/2016/06/ti dak-ada-wawali-sampai-2018.html diakses pada hari Senin, 22 Januari 2018 pukul 1:22

http://regional.kompas.com/read/2017/01/ 19/15010031/dua.tahun.tanpa.penda mping.wali.kota.cirebon.kewalahan diakses pada hari Senin, 22 Januari 2018 pukul 1:23

https://aboutcirebon.id/hari-terakhirpendaftaran-pasangan-azis-eti-resmidaftar-ke-kpu-kota-cirebon/ diakses pada hari Senin, 22 Januari 2018 pukul 1:24

http://jabar.tribunnews.com/2018/01/19/na srudin-azis-akan-serahkan-surat-cutike-kpu-kota-cirebon-hari-ini diakses pada hari Senin, 22 Januari 2018 pukul 1:26

http://diy.kpu.go.id/web/2016/06/27/memil ih-pemimpin-berkualitas/ diakses pada hari Senin, 22 Januari 2018 pukul 1:27

http://jabar.tribunnews.com/2018/01/10/di dukung-banyak-partai-petahanakota-cirebon-optimistis-menangpilkada-2018 diakses pada hari Senin, 22 Januari 2018 pukul 1:28

https://id.wikipedia.org/wiki/Nasrudin_Azi s pada tanggal 19 Januari 2018 pukul 22;15 